\title{
AUSTRALIAN PUBLIC UNIVERSITIES VICE-CHANCELLOR SALARIES AND WORKFORCE CASUALISATION: ETHICAL TENSION?
}

\section{Roberto BERGAMI}

University of South Bohemia, Faculty of Economics, Department of Trade, Tourism and Language, Studentská 13, 37005 České Budějovice, Czech Republic, email: rbergami@ef.jcu.cz

Cite this article: Bergami, R. (2021). Australian Public Universities Vice-Chancellor Salaries and Workforce Casualisation: Ethical Tension? Deturope. 13(3), 130-141.

\begin{abstract}
Australian public universities' Vice-Chancellors (VC) are among the highest paid in the world, with an individual average yearly income in excess of one million Australian Dollars, or about twice the annual income of the Prime Minister. Although universities are significantly government funded, they individually set their VC remuneration. Recent estimates put VC salaries at least 10 time that of an average lecturer' income. The rationale given for such high salaries is that $\mathrm{VC}$ perform roles that are synonymous with those of free enterprise CEOS and, therefore, they should be remunerated accordingly. However, universities are neither free enterprises, nor do they operate in a 'free-market', as student fees are controlled by the government and universities cannot simply act as an entrepreneur and manipulate prices. As government funding continues to shrink, universities have reduced the permanent academic workforce, replacing this with casual academics, employed on precarious contracts that provide no job security, and raise questions over the long-term quality of education. This paper highlights some of the ethical dilemmas of this environment and offers suggestions for changing the status quo.
\end{abstract}

Keywords: Australian universities, academic workforce casualization, vice-chancellor salaries, quality of education.

\section{INTRODUCTION}

This paper focuses on the issue of continually increasing Australian universities' ViceChancellors' (VC) salaries in an environment of staff reduction to contain costs. Some background is firstly provided about Australia and its neo-liberal approach to health and education, before outlining the methodology and providing a brief select literature review. A comparison of university and private enterprise structures is offered, prior to the discussion on the fairness of increasing VC salaries and shrinking the university workforce, before offering ideas for a more equitable VC pay structure and reaching the conclusion.

Australia's population as at 20 September 2020 was 25,693,059 people (Australian Bureau of Statistics, 2021), with 39 public and four private universities in the nation. In the Englishspeaking world, Australia's education system is highly regarded, and in the context of the university sector on a global basis, it is commonly accepted that it ranks as the third global 
'powerhouse' for international student destinations. Whilst the USA and the UK hold the first two places, Australia is well ahead of other competitor nations, such as New Zealand and Canada.

Australia's relative success in the international university student environment has largely been attributed to its profile, that encompasses a 'clean and green' image, with many natural wonders and unique flora and fauna, a country that prides itself on freedom of the people and, therefore, highly democratic and also politically stable. Perhaps the greatest attribute insofar as international students are concerned is the relatively high safety of the Australian society. Unlike other nations, such as the USA and some European nations, terrorism is not as widespread in Australia and mass shootings are a rarity indeed. The safety of the nation, coupled with its achievements in research and innovation, especially in the health sciences, as well as its reputation for quality education, assist in painting a 'positive picture' that tends to attract foreign students to study onshore. The focus on foreign students is an important factor for Australian universities, as discussed later in this paper.

Australia's university landscape, in recent decades, has been heavily influenced by the neoliberal ideology that believes in the mantra of the free market, one that is economically selfsustaining. Yet, there is a plethora of evidence of free market failures, and I argue the neoliberal ideology ignores some of the realities of the world we live in and is not particularly tolerant of societal and social needs. I am particularly critical of the neo-liberal ideology in two areas of society: health and education, both of which I regard as fundamental pillars of any modern civilisation. Although the focus of this paper is on universities, I briefly draw on the government approach to the health sector as an example of the nature of the neo-liberal approach.

In the eyes of the neo-liberal I see a common treatment of both health and education - they are both regarded as 'expense' items and almost given the same treatment. Consequently, the neo-liberal government wants to find solutions to 'fix' the problem by, essentially, privatising it, thereby 'removing' the expenditure from the liability side of their ledger. However, this does not work very well, if at all. As an example, in Australia, attempts have been made to privatise the health system, at least in part. This has resulted in the federal government providing taxpayer funded subsidies to private health providers, to help them survive, as they struggle to attract fee paying members. A significant proportion of the population still prefers to rely on the free publicly funded health system, as shown in Fig. 1. 
Figure 1 Private health insurance statistics as at December 2020

\section{Key metrics}

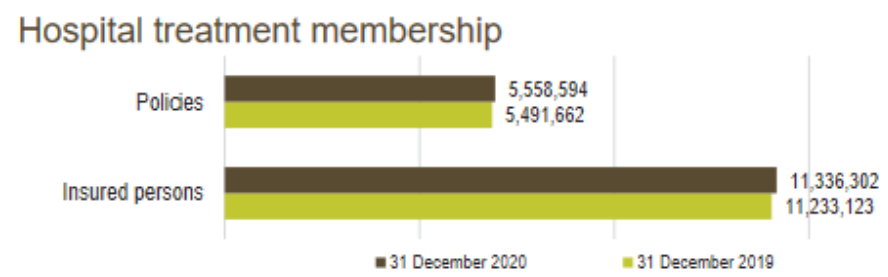

43.9\% of population at 31 December 2020

$0.0 \%$ percentage points from 30 Sep 2020

34,801 insured persons over the quarter

Source: (Australian Prudential Regulation Authority, 2021)

The Australian federal government actively 'encourages' individuals to take private health hospital insurance, for failing do so triggers the application of an additional taxation levy (Australian Taxation Office, 2020). This is a way to ensure the private health funds remain viable (whilst receiving government subsidies). The anomaly in this setting is that if the neoliberal ideology is to let the free market operate, logically, there should be no place/need for government subsidies, indeed this would be an anathema to that ideology, but politics produce strange phenomena at times.

I argue that the fundamental problem with the neo-liberal ideology is that it ignores market failures and the fact that the private enterprise operates on creating profit, consequently, it will only engage in those activities from which it can derive economic benefit, resulting in 'cherrypicking' (selective involvement). This has been observed in the vocational education and training (VET) sector of the Australian education system.

The VET system was introduced to the concept of 'managed competition' during the 1990's (Bowman \& McKenna, 2016). Private providers - Registered Training Organisations (RTOs) were offered government subsidy to compete with publicly funded Technical and Further Education (TAFE) institutions. The rationale behind this move was that TAFE was inefficient and a drain on the public purse. The curious situation that developed was that of pitting government funding against itself, competing for the same student body - significantly, the domestic student market is static, so these policies did not increase the numbers of students. Rather, these policies merely provided RTOs with the option of obtaining significant government subsidy from which to derive a profit. The majority of these RTOs did not offer the full complement of programs that their TAFE counterpart offered, an example of cherrypicking, and their questionable education practices were the subject of much controversy (Aird \& Branley, 2014; Dodd, 2016). 
The university sector, so far, has been spared the treatment given to the VET sector, but has, nevertheless, been subjected to continuing funding cuts over the years, especially under successive right-wing governments, who appear to be staunch believers in the free market mantra (but nevertheless subsidise free market activities). These governments have purposely changed the traditional notion of what a university is. As Star (2007) explains, "universities are now conceived as corporations providing a private good for individual consumers. New priorities, funding arrangements and governance structures within universities emphasise commercialisation" (p. 2). Indeed, Rea (2016) claims that "marketisation of our public universities is emblematic in public university vice chancellors no longer being seen as leaders of a community of scholars but re-cast as CEOs answering to university councils (which are now more akin to corporate boards of management overseeing the operation of large enterprises) (p. 9). It is the change in the raison d'être of a university that has brought with it many challenges, some of which will be discussed in this paper.

\section{METHODOLOGY}

The methodology comprises on analysis of relevant publications based on data available from the public domain and the experiences of the authors in the field, as well as my own personal experiences. The publications presented in the literature review section will mostly be from commentators across different disciplines, with some theoretical assumptions provided to explain the reasons of the current state of VC salaries in Australia and the challenges associated in addressing these.

\section{LITERATURE REVIEW}

A select review of literature in the field of ethics as it relates to university management appears to focus on "the creation of a moral compass" (Natale \& Libertella, 2016, p. 35) by improving "the ethical climate in universities, with a proper implementation of ethics management and procedures" (Puiu \& Ogarca, 2014, p. 599) that could be instituted by "ethical codes, ethics committees, ethical audits, ethical education of staff, techniques to create an institutional culture of a moral nature [that] have all become increasingly widespread" (Gurgu \& Tonis, 2018, p. 69). According to Boyd (2009) academic governance should be evaluated across the "scales of policy, process and practice" (p. 8). 
Other literature focuses on wage cuts and organisational empathy (Dietz \& Kleinlogel, 2014) and "the ethical dilemma of whether employees or owners should bear the cost of a crisis" ( $p$. 461) - an appropriate consideration in the context of this paper. McGuire, Dow, and Argheyd (2003) consider the "relationship between CEO incentives and string and weak corporate social performance" (p. 341). According to these authors, incentives bear little weight on strong social performance, whereas "salary and long-term incentives have a positive association with weak social performance" (p. 341). Jacques (2003) argues that corporate governance and

people-management systems and practices ... both allow and require behaviours that are in direct opposition to requisite business ethical behaviours and undermine such behaviour. These problems include weak and non-articulated accountabilities and authorities, lack of long-term ownership concerns in shareholders and elected boards, compensation systems that alienate people and require selfish and even corrupt behaviors, if you are to get ahead and so on (p. 136).

There is some correlation between Jacques's (2003) claims and university governance, as there are no shareholders as such and appointments to councils (governance bodies) can appear opaque and there is a lack of clarity on their accountability and responsibility - who do they answer to in the end? What happens if they make an incorrect decision? The perception seems to be that there are no penalties. It is councils that set VC salaries, so they play an important financial role in the university. There is mounting evidence on the corporatisation of councils, as "over the past 15 years or so, federal and state legislation has reconstituted these councils to favour members with no tertiary experience" (Lucas et al., 2020).

Bishop (2004) ponders whether corporate salaries are a form of bribe, and this author's work is relevant to this paper in the context of the obligations posed on executives as a result of the their salaries. Bishop (2004) believes "there are serious reasons for moral concern" (p. 9) where the executive may experience difficulties between acting “in the corporation's interest even if this conflicts with some sort of existing obligations to families, communities or other people or groups" (p. 9). In the context of VCs, we may ponder as to whether seemingly excessive salaries and reduction in staff numbers cause moral concerns. I must point out that I am not accusing or suggesting VCs to be corrupt.

VC salaries have been the subject of recent criticism. Some of this criticism has centred on how these individuals have managed to achieve such generous salaries, that are much higher than their peers in the UK, and certainly much higher than the Australian Prime Minister (van Onselen, 2020). Other critics have pointed to the burgeoning VC salaries and university profits, 
whilst decrying chronic casual staff underpayments, as "least 10 Australian universities have admitted to underpaying casual staff, having to audit payments to staff or to being in industrial disputes with staff' (Sainsbury, 2020) - hardly a good ethical approach. According to Fisher and Tronto (1940) "ethics is a species activity that includes everything we do to maintain, continue and repair our world so we can live in it as well as possible" - underpayment of staff at one end, whilst increasing executive salary at the other end does not reflect an ethical approach. The usual excuse given for underpayment of staff is a complex industrial relation system, with difficult to interpret awards and enterprise bargaining agreement (EBA) clauses, but in the case of Australian universities, wages are typically easily to work out under the schedules attached to such EBAs.

Heffernan (2019) points to the largely negative narrative espoused by the media on VC salaries and argues that the role of a VC has evolved as "they now essentially carry out the role of a university CEO” (p.14). This author further argues that

the media and public continue to view universities as educational institutions, but this view needs to be better represented so that universities can also be seen as billion-dollar organisations, where the VCs are tasked with similar duties to CEOs and tasked with similar duties to CEOs of similarly-sized organisations, even if the traditional title of vice-chancellor remains the same (p. 14)

Certainly, "neoliberal reforms in higher education have resulted in corporate managerial practices in universities (Kenny, 2017, p. 897), and "over the period 1999-2004, the remuneration of academic executives has increased by more than $30 \%$, which is about twice the increase in the salaries of teaching and research academics". Baker (2020) reports that "Australian vice-chancellors out-earn their counterparts in the United Kingdom, where salaries are also a touchy issue. They also earn more than Australia's Reserve Bank governor ( $\$ 1$ million) and the prime minister $(\$ 549,250)$. Last year, the median pay of chief executives of ASX 100 chief executives was \$1.76 million”.

\section{DISCUSSION}

Neo-liberalism is founded on the premise of a "perfect" market", itself an economic misnomer, as in reality perfection in human activity does not exist. Universities are unique organisations that perform a central role in advancing society through rigour in teaching and research and are often at the forefront of new discoveries, through the application of theories into practice. It is 
commonly accepted that the attainment of higher education levels advances progress and leads to an increase of an individual's wealth. Traditionally universities have been government funded and, as such, are a public asset, in essence 'owned' by taxpayers.

In Australia, as evidenced by the existing literature, the status of universities began to change through the application of neo-liberal principles, changing the raison d'être of a university from that of an institution for the public good into a quasi-corporation, with structures similar to those of private, profit-making entities. Of course, those at the helm of such universities have largely followed suit with remuneration packages that mimic the private sector. Yet there are significant differences between universities and private enterprise, that include:

- Universities are not for profit organisations, as they are still significantly funded by the government;

- Universities do not have shareholders, so the concept of shareholder wealth has no meaning in this context;

- University fees are controlled by the government for domestic students, therefore, a university cannot simply "increase the price" of its services (courses/programs of study);

- There is a considerably longer pipeline of students in the system from enrolment to completion, that is not easily matched to other products/services offered in the open market. The standard undergraduate program is three years full-time or six years parttime. Students should not be thought of as customers, because the reality of university studies is unlike any other product in the free market. Which product or service asks you to pay money (university fees can be deferred to after completion, but they still have to be repaid), to undertake a three to year course of study that does not give you any guarantee of outcomes in either passing (or the score level against each unit of study) or employment on completion?

Despite the above differences, the neo-liberal approach has prevailed and now we see Australian universities expected to behave like corporate entities. Indeed, university governance has been modelled from board of directors' structures. In fact, one may argue that not much has changed since medieval times in terms of general governance structures, as shown in Figure 2. It can be clearly observed that the modern university structure in Australia is a virtual replica of the corporate world with, increasingly, individuals being appointed to critical roles in an education institution that lack background in the education sphere, making one wonder as to how the best decisions for the universities may be made. 
Figure 2 Corporate structures over time
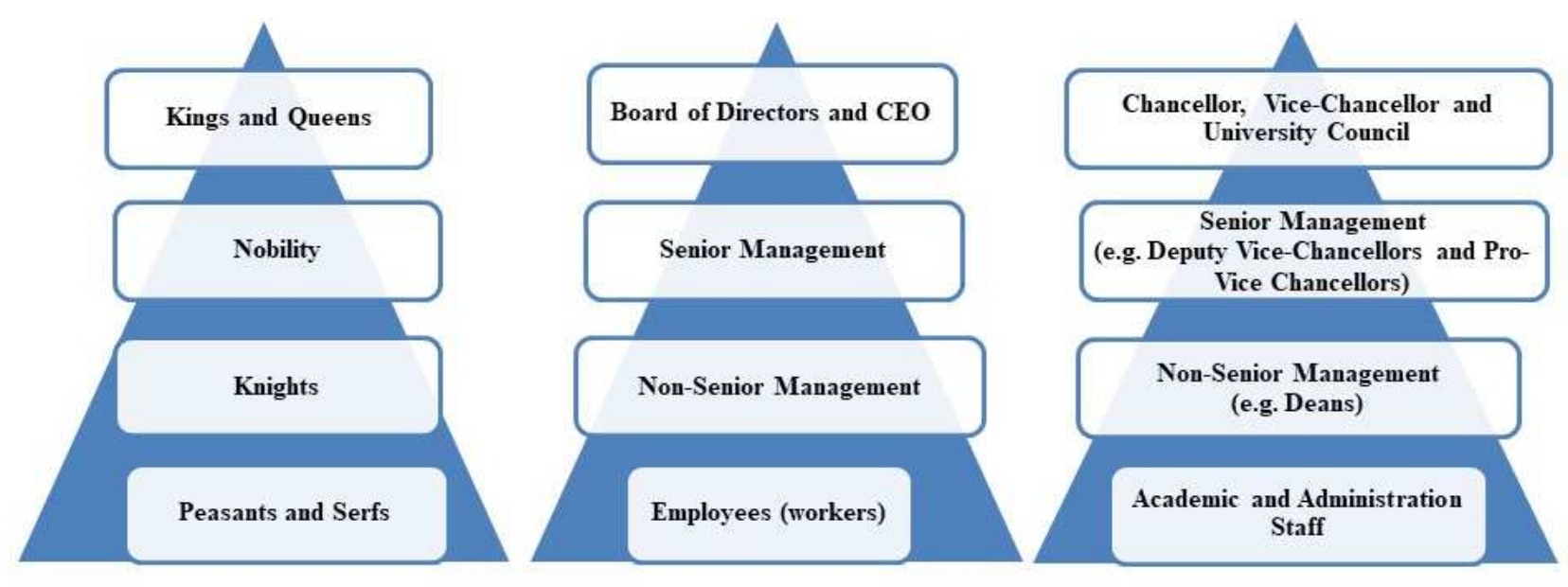

Time

Source: Adapted from Bergami (2019)

Within the governance structure of the university, we have the VCs, who play a crucial role in steering the institution and are, of course, handsomely rewarded for their efforts. Who sets VCs' salaries? The university council. How is the university council membership decided? Nowadays "council members without tertiary experience now vastly outnumber those with it, and vicechancellors have been empowered to determine many of the appointments" (Lucas et al., 2020). Is there not at least an apparent conflict of interest in this scenario? VCs appoint council members who in turn decide on VCs salaries - this should be cause for alarm on ethical grounds. As an example, at one Australian university

the Performance and Remuneration Committee (which determines the VC's salary and performance) consists only of the chancellor, the deputy chancellor and two of the council's external members. The council is responsible for managing its own performance, including any potential conflicts of interest for external members. Council minutes are not publicly available. This prevents external scrutiny of council deliberations (Lucas et al., 2020).

The concern with VCs' salaries, apart from their largesse, is that the rise in remuneration has occurred at the same time as significant staff reduction, resulting in workforce casualisation and whatever staff are left behind have been pressured into doing higher grade jobs for essentially lesser pay. As an example, lecturers A (the lowest level) are now routinely doing course coordination work, which has traditionally been the domain of a Lecturer C (Senior Lecturer), because this role requires a lot of expertise knowledge of courses, their interaction with each other and a high degree of pastoral care when making decisions about students. The shift to having less experienced staff doing higher level duties has resulted in a reduction of staffing 
costs, but at what other costs: educational integrity? quality of learning and teaching? Curiously we have witnessed a reduction in overall staffing at universities whilst at the same time VC salaries have increased. Cynically one may argue this is a mere accounting trick to shift wealth., as is evidenced by the constant increase shown in Figure 3. The only exception to VC salaries growth has been in dual sector institution that offer both university and vocational education courses, however the reasons for this anomaly are not known and, in any case these are only four such institutions in the nation, consequently they are a minority representation.

Figure 3 Ratio of Australian VC to lecturer pay, 1975-2018

Remuneration of public university vice-chancellors compared to level B lecturers

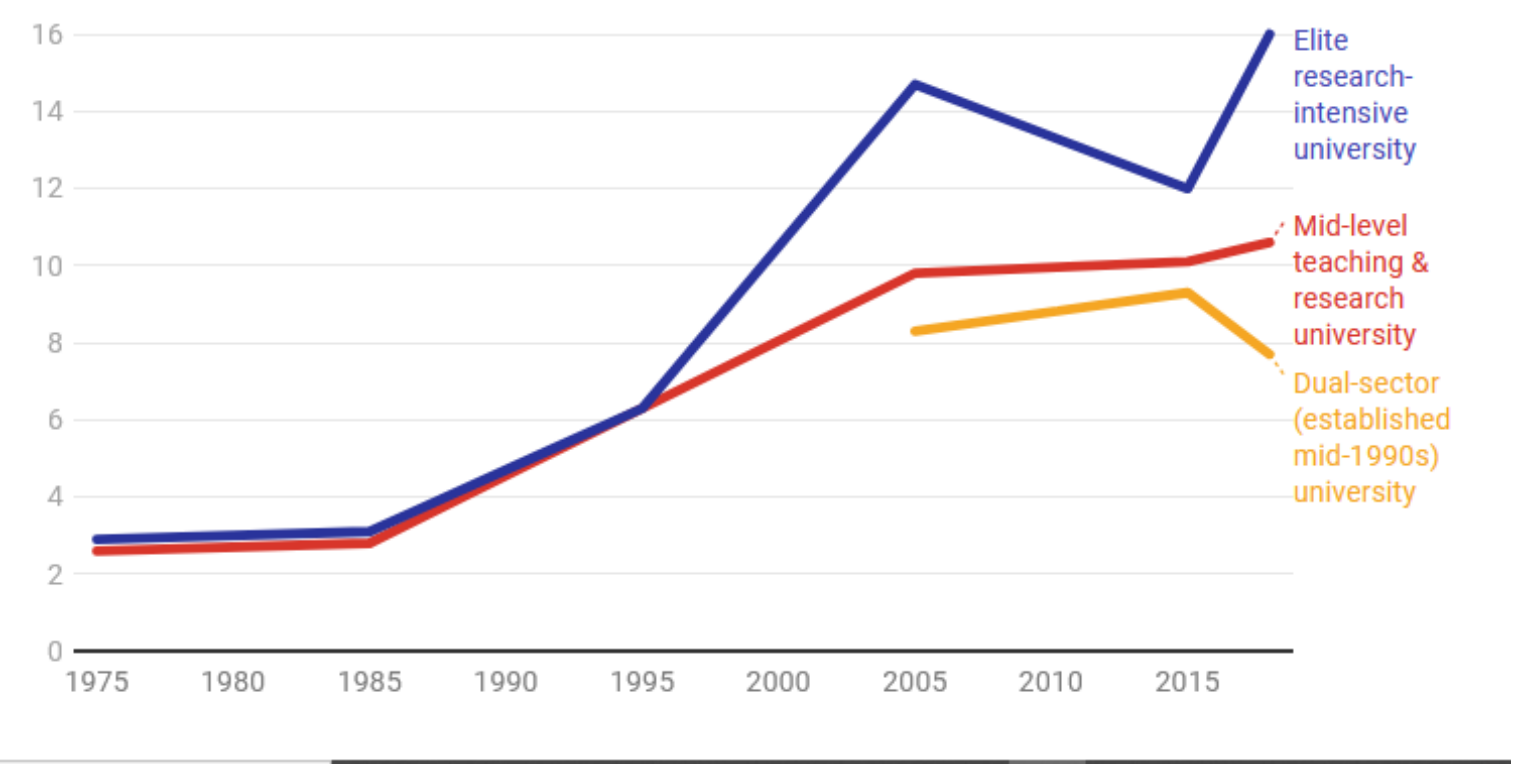

Source: Rowlands and Bowen (2020)

Figure 3 suggests there is a case of pay employees less and reward executives more - where are the ethical consideration in this environment?

I argue that VC salaries are far too high for a university that is still publicly funded and that should represent the needs of its community and exist for the greater good of the nation and its society. Consequently, I propose some changes to address the question of VCs' salaries, through a more ethical approach as outlined below. In any of these proposals, I argue that one of the key measures should be no increase to a VC's salary where staffing reduction occurs in the period of remuneration.

1. VC remuneration should not be set by university councils, in their current format. I propose that the composition of university councils be changed by removing government 
appointees in order to achieve a balanced representation from staff, students, alumni and the community the university primarily serves; or

2. If councils are not easily changed, then $\mathrm{VC}$ remuneration should, at the very least, be removed from council authority and vested in a separate independent unit within the university with the same membership criteria identified above; or

3. Setting up a national remuneration body for VC salaries that sets common benchmarks and targets across the nation leading to a level playing field. This body should have no government appointments and operate independently. Remuneration should be directly related to key performance indicators that are fair, transparent and easily measurable.

\section{CONCLUSION}

There has been some disquiet in the media and academic literature about the largesse of Australian universities VCs' salaries. Most of the comments have been quite negative and question the validity of such high remuneration, especially since these have occurred in an environment of staff reduction and concurrent increase in VCs' salaries.

This paper has sought to highlight some of the 'disjoints' of the current Australian university sector, proposing a number of solutions that should foster a greater ethical environment in relation to VCs' remuneration. Change to the current status quo is, and should be, pursued as, after all, university expenditure should be a matter of concern to the nation, as these institutions are still predominantly government funded and accountability and transparency should be the order of the day. The proposals in this paper aim to counteract the neo-liberal approach that has made the modern Australian university of today.

\section{REFERENCES}

Aird, C., \& Branley, A. (2014, 6 October). Unregistered training colleges target disadvantaged, sign them up to expensive government loans. $A B C$ News. Retrieved from https://www.abc.net.au/news/2014-10-06/unregistered-training-colleges-target-lowincome-earners/5793246

Australian Bureau of Statistics. (2021, 18 March). National, state and territory population. Retrieved from https://www.abs.gov.au/statistics/people/population/national-state-andterritory-population/sep-2020

Australian Prudential Regulation Authority. (2021). Quarterly private health insurance statistics - December 2020. Retrieved from Sydney, NSW, Australia: https://www.apra.gov.au/ sites/default/files/2021-02/Quarterly\%20private $\% 20$ health $\% 20$ insurance $\% 20$ statistics $\%$ 20December\%202020.pdf 
Australian Taxation Office. (2020, 27 October 2020). Medicare levy surcharge. Retrieved from https://www.ato.gov.au/individuals/medicare-and-private-health-insurance/medicarelevy-surcharge/

Baker, J. (2020, 20 November). Are heads of Australian universities worth a million dollars? Retrieved from https:/www.smh.com.au/national/are-heads-of-australian-universitiesworth-a-million-dollars-20201120-p56gga.html

Bergami, R. (2019). Twenty-First Century Feudalism in Australian Universities. In B. D. \& M. C. (Eds.), Resisting Neoliberalism in Higher Education (Vol. 1, pp. 37-58). Cham, Switezrland: Palgrave Macmillan.

Bishop, J. D. (2004). Crossing the boundaries of obligation: Are corporate salaries a form of bribery? Journal of Business Ethics, 55, 1-11.

Bowman, K., \& McKenna, S. (2016). The development of Australia's national training system: a dynamic tension between consistency and flexibility. Adelaide, SA, Australia: NCVER.

Boyd, B. (2009). Evaluating academic governance processes and structures: Ethical dilemmas and academic governance development. Paper presented at the 7th Annual Australasian Higher Education Evaluation Forum, "Evaluation in a changing higher education landscape: Bradley and beyond", Byron Bay, NSW, Australia. https://www.scu.edu.au/aheef/index.php/7/

Dietz, J., \& Kleinlogel, E. (2014). Wage cuts and managers' empathy: How a positive emotion can contribute $t$ positive organizational ethics in difficult times. Journal of Business Ethics(119), 461-472.

Dodd, T. (2016, 21 May). Private college's VET FEE-HELP loan scandal hit: \$160 million and counting. The Australian Financial Review. Retrieved from https://www.afr.com/policy/ health-and-education/private-colleges-vet-feehelp-loan-scandal-hit-160-million-andcounting-20160519-gozbmp

Fisher, B., \& Tronto, J. (1940). Circles of care work and identity in women's lives. In E. K. Abel \& M. K. Nelson (Eds.), Towards a feminist theory of caring. New York, NJ, USA: University Press.

Gurgu, E., \& Tonis, R. (2018). Ethical universities of integrity and ethics management in the Romanian university environment. Journal of Economic Development, Environment and people, 7(4), 69-79.

Heffernan, T. A. (2019). Reporting on vice-chancellor salaries in Australia's and the United Kingdom's media in the wake of strikes, cuts and 'falling performance'. International Journal of Leadership in Education, 1-17. doi:10.1080/13603124.2019.1631387

Jacques, E. (2003). Ethics for management. Management Communications Quarterly, 17(1), 136-142.

Kenny, J. (2017). Academic work and performativity. Higher Education, 74, 897-913.

Lucas, A., Whelan, A., Probyn-Rapsey, F., Tackacs, G., Svirsky, M., \& Verucci, N. (2020, 4 September). Governing universities: tertiary experience no longer required. Retrieved from https://theconversation.com/governing-universities-tertiary-experience-no-longerrequired-145439

McGuire, J., Dow, S., \& Argheyd, K. (2003). CEO incentives and corporate social performance. Journal of Business Ethics, 45, 341-359.

Natale, S. M., \& Libertella, A., F. (2016). Higher education and wealth equity: Calibrating the mora compass empathy, ethics and the trained will. Journal of Academic Ethics, 14, 35 47.

Puiu, S., \& Ogarca, R. F. (2014). Ethics management in higher education system of Romania. Paper presented at the 2nd Global conference on business, economic, management and tourism, Prague, Czech Republic. 
Rea, J. (2016). Critiquing neoliberalism in Australian universities. Australian Universities Review, 58(2), 9-14.

Rowlands, J., \& Bowen, R. (2020, 2 December). How Australian vice-chancellors' pay came to average $\$ 1$ million and why it's a problem. Retrieved from https://theconversation.com/how-australian-vice-chancellors-pay-came-to-average-1million-and-why-its-a-problem-150829

Sainsbury, M. (2020). Australia's universities: bosses reel in $\$ 1 \mathrm{~m}-$ plus salaries, $\$ 1$ bn profit on back of staff underpayment. Retrieved from https://www.michaelwest.com.au/australianuniversity-profits/

Star, C. (2007, 26-29 September). Whither engagement? Challenges for community engagement within academia. Paper presented at the 2007 International Women's Conference: Education, Employment and Everything... the Triple Layers of a Woman's Life, Toowoomba, Queensland, Australia.

van Onselen, L. (2020, 21 April). How greedy university VCs fattened themselves on international students Retrieved from https://www.macrobusiness.com.au/2020/04/ greedy-university-vcs-must-cut-their-fat-salaries/ 